\title{
PRINSIP KHUSUS DAN JENIS LAYANAN PENDIDIKAN BAGI ANAK TUNAGRAHITA
}

\author{
Ni Luh Gede Karang Widiastuti ${ }^{1)}$, I Made Astra Winaya ${ }^{2)}$ \\ Program Studi Pendidikan Guru Sekolah Dasar ${ }^{1)}$, Universitas Dwijendra ${ }^{2)}$, \\ E-mail: karangwidhi@gmail.com ${ }^{1)}$,winaya@undwi.ac.id ${ }^{2}$
}

\begin{abstract}
ABSTRAK
Artikel ini disusun dengan maksud untuk memberikan jawaban atas permasalahan yang sering kali muncul dan dihadapi guru di sekolah. Salah satu permasalahan yang sering kali terjadi adalah berkaitan dengan kondisi siswa yang dalam konteks ini adalah anak-anak tunagrahita. Anak tunagrahita adalah anak yang memiliki inteligensi yang signifkan berada dibawah rata-rata dan disertai dengan ketidakmampuan dalam adaptasi perilaku yang muncul dalam masa perkembangan. Anak tunagrahita mempunyai hambatan akademik yang sedemikian rupa sehingga dalam layanan pembelajarannya memerlukan modifikasi kurikulum yang sesuai dengan kebutuhan khususnya. Anak-anak tunagrahita ringan maupun sangat berat memerlukan layanan pendidikan khusus dalam proses pembelajarannya di sekolah. Mereka membutuhkan bimbingan dan program yang sesuai dengan kebutuhan belajarnya agar mereka memiliki masa depan yang cerah, sama seperti anak pada umumnya.
\end{abstract}

Kata Kunci: Anak Tunagrahita, Pendidikan, Layanan Pendidikan Khusus

\section{ABSTRACT}

This article is structured with the intention of providing answers to questions that often arise and are discussed by teachers at school. One that often happens is what happens to students who in this context are mentally retarded children. Mentally retarded children are children who have significant intelligence with abilities and inability to adapt that arise in future developments. Mentally retarded children have academic abilities that are in accordance with the needs of their learning services requiring curriculum modification to suit their specific needs. Mild mentally retarded children also need special education services in the learning process at school. They need guidance and programs that suit their learning needs so that they have a bright future, just like children in general.

Key words: Mentally Retarded Children, Education, Special Education Services

\section{PENDAHULUAN}

Banyak terminologi (istilah) yang digunakan untuk menyebut mereka yang kondisi kecerdasannya di bawah rata-rata seperti mental retardation, mental deficiency, mentally handicapped, feebleminded, mental subnormality. Beragamnya istilah yang digunakan disebabkan oleh perbedaan latar belakang keilmuan dan kepentingan para ahli yang mengemukakannya. Namun demikian, semua istilah tersebut tertuju pada pengertian yang sama, yaitu menggambarkan kondisi terlambat dan terbatasnya perkembangan kecerdasan seseorang sedemikian rupa jika dibandingkan dengan rata-rata atau anak pada umumnya disertai dengan keterbatasan dalam perilaku penyesuaian. Keterlambatan dalam perkembangan kecerdasannya, anak tunagrahita akan mengalami berbagai hambatan dalam upaya memenuhi kebutuhan-kebutuhan, bahkan diantara mereka ada yang mencapai sebagaian atau kurang, tergantung pada berat ringannya hambatan yang dimiliki anak serta perhatian yang diberikan oleh 
lingkungannya. Kondisi ini tentu saja menjadikan persoalan tersendiri dalam pemberian layanan yang sesuai dengan kebutuhan masing-masing anank tunagrahita. Namun demikian, banyak diantara guru-guru atau sekolah yang belum menyadari dan belum memberikan pelayanan pendidikan khusus sesuai dengan kebutuhan siswa tubagrahita. Hal ini tidak terlepas dari kurangnya pengetahuan guru dalam menemukenali ciri-ciri dan karakteristik dari anak tunagrahita.

Berdasarkan hal tersebut, diperlukan pemberian pengetahuan atau pelatihan khusus bagi guru maupun calon guru untuk menemukenali ciri-ciri dan karakteristik anak tunagrahita. Dimana, secara garis besar anak tunagrahita dapat diklasifikasikan menjadi tunagrahita ringan IQ nya (50-70), tunagrahita sedang IQ nya (30-50), tunagrahita berat dan sangat berat IQ nya kurang dari 30 .

Mengingat adanya variasi jenis ketunagrahitaan, maka pelayanan pendidikan dengan pendekatan khusus akan sangat sesuai untuk memenuhi kebutuhanya. Walaupun demikian, pada hakekaktnya perbedaan ketunagrahitaan pada anak memiliki keterkaitan langsung dalam proses belajar anak sehingga diperlukan keterampilan dari seorang guru dalam memahami prinsip dan jenis layanan pendidikan serta mampu menyusun strategi, media maupun evaluasi penilaian dalam proses pembelajaran dalam konteks pemberian layanan pendidikan yang sesuai.

\section{PEMBAHASAN}

\section{Pengertian Anak Tunagrahita}

Istilah yang digunakan untuk menyebut Anak Tunagrahita cukup beragam. Dalam bahasa Indonesia, istilah yang pernah digunakan, misalnya lemah otak, lemah ingatan, lemah pikiran, retardasi mental, terbelakang mental, cacat grahita, dan tunagrahita. Dalam Bahasa asing (Inggris) dikenal dengan istilah mental retardation, mental deficiency, mentally handicapped, feebleminded, mental subnormality (Moh. Amin, 1995: 20). Istilah lain yang banyak digunakan adalah intellectually handicapped dan intellectually disabled. Beragamnya istilah yang digunakan disebabkan oleh perbedaan latar belakang keilmuan dan kepentingan para ahli yang mengemukakannya. Ada beberapa ahli yang mengungkapkan pengertian dari tunagrahita itu sendiri, sebagai berikut :

a. Menurut AAMD (Moh., 1995)

Mendefinisikan tunagrahita sebagai kelainan yang meliputi fungsi intelektual umum di bawah rata-rata, yaitu IQ 84 ke bawah berdasarkan tes dan muncul sebelum usia 16 tahun. Sejalan dengan definisi tersebut, AFMR (Vivian, 1987) menggariskan bahwa seseorang yang dikategorikan tunagrahita harus melebihi komponen keadaan kecerdasannya yang jelas-jelas di bawah rata-rata, adanya ketidakmampuan dalam menyesuaikan diri dengan norma dan tuntutan yang berlaku di masyarakat.

b. Menurut Endang Rochyadi dan Zainal Alimin (2005)

Menyebutkan bahwa tunagrahita berkaitan erat dengan masalah perkembangan kemampuan kecerdasan kemampuan kecerdasan yang rendah dan merupakan sebuah kondisi. Hal ini ditunjang dengan penyataan dari Kirk (Muhammad Efendi, 2006) yaitu "Mental Retarded is not a disease but a 
condition". Jadi dapat dipertegas tunagrahita merupakan suatu kondisi yang tidak bisa disembuhkan dengan obat.

Menurut Endang Rochyadi (2005) Dari definisi tersebut, beberapa hal yang perlu kita diperhatikan adalah berikut ini.

a. Fungsi intelektual umum secara signifikan berada di bawah rata-rata, maksudnya bahwa kekurangan itu harus benar-benar meyakinkan sehingga yang bersangkutan memerlukan layanan pendidikan khusus. Sebagai contoh, anak normal rata-rata mempunyai IQ (Intelligence Quotient) 100, sedangkan anak tunagrahita memiliki IQ paling tinggi 70.

b. Kekurangan dalam tingkah laku penyesuaian (perilaku adaptif), maksudnya bahwa yang bersangkutan tidak/kurang memiliki kesanggupan untuk melakukan pekerjaan-pekerjaan yang sesuai dengan usianya. Ia hanya mampu melakukan pekerjaan seperti yang dapat dilakukan oleh anak yang usianya lebih muda darinya.

c. Ketunagrahitaan berlangsung pada periode perkembangan, maksudnya adalah ketunagrahitaan itu terjadi pada usia perkembangan, yaitu sejak konsepsi hingga usia 18 tahun.

Berdasarkan uraian di atas jelaslah bahwa untuk dikategorikan sebagai penyandang tunagrahita, seseorang harus memiliki ketiga ciri-ciri tersebut.

\section{Klasifikasi Anak Tunagrahita}

Pengklasifikasian anak tunagrahita penting dilakukan untuk mempermudah guru dalam menyusun program dan melaksanakan layanan pendidikan. Klasifikasi Anak Tunagrahita yang digunakan saat ini di Indonesia adalah (PP No.72/1999) sebagai berikut:

a. Tunagrahita Ringan IQ nya (50-70)

b. Tunagrahita Sedang IQ nya (30-50)

c. Tunagrahita Berat dan Sangat Berat IQ nya kurang dari 30

Klasifikasi menurut AAMD (Moh, 1995), sebagai berikut:

a. Tunagrahita Ringan (Mampu Didik)

Tingkat kecerdasannya IQ mereka berkisar 50-70, mempunyai kemampuan untuk berkembang dalam bidang pelajran akademik, penyusuaian sosial dan mampu bekerja, mampu menyusuaikan lingkungan yang kebih luas, dapat mandiri dalam masyarakat, mampu melakukan pekerjaan semi trampil dan pekerjaan sederhana.

b. Tunagrahita Sedang (Mampu Latih)

Tingkat kecerdasan IQ nya berkisar 3050, dapat belajar keterampilan sekolah untuk tujuan fungsional, mampu melakukan keterampilan mengurus dirinya sendiri, mampu mengadakan adaptasi sosial dilingkungan terdekat, mampu mengerjakan pekerjaan rutin yang perlu pengawasan.

c. Tunagrahita Berat dan Sangat Berat (Mampu Semangat)

Tingkat kecerdasan IQ nya kurang dari 30 hampir tidak memiliki kemampuan untuk dilatih mengurus diri sendiri. Ada yang masih mampu dilatih mengurus diri sendiri, berkomunikasi secara sederhana, dan dapat menyesuaikan diri dengan lingkungan sangat terbatas.

Klasifikasi Anak Tunagrahita berdarkan tipe-tipe klinis/fisik (Mumpuniarti, 2007), sebagai berikut:

a. Down Syndrome (Mongolisme)

Terjadi akibat kerusakan khromozon. Anak tunagrahita jenis ini disebut 
demikian karena memiliki raut muka menyerupai orang Mongol dengan mata sipit dan miring, lidah tebal suka menjulur ke luar, telinga kecil, kulit kasar, susunan gigi kurang baik.

b. Kretin (Cebol)

Ada gangguan hiporoid. Anak ini memperlihatkan ciri-ciri, seperti badan gemuk dan pendek, kaki dan tangan pendek dan bengkok, kulit kering, tebal, dan keriput, rambut kering, lidah dan bibir, kelopak mata, telapak tangan dan kaki tebal, pertumbuhan gigi terlambat.

c. Hydrocephal

Terjadi karena cairan otak yang berlebihan. Anak ini memiliki ciri-ciri kepala besar, raut muka kecil, pandangan dan pendengaran tidak sempurna, mata kadang-kadang juling.

\section{d. Microcephal}

Anak ini memiliki ukuran kepala yang kecil.

e. Macrocephal

Anak ini memiliki ukuran kepala yang besar.

\section{Tujuan Pendidikan Anak Tunagrahita}

Tujuan pendidikan anak tunagrahita dikemukakan oleh Suhaeri HN (1980) sebagai berikut.

a. Tujuan pendidikan anak tunagrahita ringan adalah (1) agar dapat mengurus dan membina diri; (2) agar dapat bergaul di masyarakat; dan (3) agar dapat mengerjakan sesuatu untuk bekal hidupnya.

b. Tujuan pendidikan anak tunagrahita sedang adalah (1) agar dapat mengurus diri, seperti makan minum, berpakaian, dan kebersihan badan; (2) agar dapat bergaul dengan anggota keluarga dan tetangga, serta
(3) agar dapat mengerjakan sesuatu secara rutin dan sederhana.

c. Tujuan pendidikan anak tunagrahita berat dan sangat berat adalah (1) agar dapat mengurus diri secara sederhana (memberi tanda atau katakata apabila menginginkan sesuatu, seperti makan), (2) agar dapat melakukan kesibukan yang bermanfaat (misalnya mengisi kotak-kotak dengan paku); (3) agar dapat bergembira (seperti berlatih mendengarkan nyanyian, menonton TV, menatap mata orang yang berbicara dengannya).

\section{Jenis Layanan Pendidikan Anak Tunagrahita}

Pendidikan anak tunagrahita bukanlah program pendidikan yang seluruhnya terpisah dan berbeda dari pendidikan umum. Anak tunagrahita sangat memerlukan pendidikan serta layanan khusus yang berbeda dengan anak-anak pada umumnya. Berikut ini akan dikemukakan hal-hal yang berkaitan dengan jenis layanan anak tunagrahita.

\section{Tempat dan Sistem Layanan Penididikan Anak Tunagrahita}

Ada beberapa pendidikan dan layanan untuk anak tunagrahita menurut Endang Rochyadi dan Zainal Alimin (2005) yaitu :

\section{a. Tempat Khusus atau Sistem Segregasi}

Sistem layanan pendidikan segregasi adalah sistem pendidikan yang terpisah dari sistem pendidikan anak normal. Tempat pendidikan yang termasuk sistem segregasi, adalah sebagai berikut.

1) Sekolah Khusus (Sekolah Luar Biasa)

Sekolah khusus untuk anak tunagrahita disebut Sekolah Luar Biasa C 
(SLB-C) dan Sekolah Pendidikan Luar Biasa C (SPLB-C). Murid yang ditampung di tempat ini khusus satu jenis kelainan atau ada juga khusus melihat berat dan ringannya kelainan, seperti sekolah untuk tunagrahita ringan. Dalam satu kelas maksimal 10 anak dengan pembimbing/pengajar guru khusus dan teman sekelas yang dianggap sama keampuannya (tunagrahita).

Penerimaan murid dilakukan setiap saat sepanjang fasilitas masih memungkinkan. Pengelompokan murid didasarkan pada usia kronologisnya dan usia mentalnya diperhatikan pada saat kegiatan belajar berlangsung. Model seperti ini tidak menyulitkan guru karena setiap anak mempunyai program sendiri. Penyusunan program menggunakan model Individualized Educational Program (IEP) atau program pendidikan yang diindividualisasikan; maksudnya program disusun berdasarkan kebutuhan tiap individu.

Jenjang pendidikan yang ada di sekolah khusus ialah Taman Kanak-kanak Luar Biasa (TKLB, lamanya 3 tahun), Sekolah Dasar Luar Biasa (SDLB, lamanya 6 tahun), Sekolah Lanjutan Tingkat Pertama (SLTPLB, lamanya 3 tahun), Sekolah Menengah Luar Biasa (SMLB, lamanya 3 tahun).

Sekolah khusus ada yang menyediakan asrama sehingga murid tunagrahita langsung tinggal di asrama sekolah tersebut. Terdapat kesinambungan program pembelajaran antara yang ada di sekolah dengan di asrama, sehingga asrama merupakan tempat pembinaan setelah anak di sekolah. Selain itu, kelas khusus berasrama merupakan pilihan sekolah yang sesuai bagi murid yang berasal dari luar daerah, karena mereka terbatas fasilitas antar jemput.

2) Sekolah Dasar Luar Biasa (SDLB)

SDLB di sini berdiri sendiri dan hanya menampung anak tunagrahita usia sekolah dasar. Model ini dibentuk agar mempercepat pemerataan kesempatan belajar bagi anak luar biasa. Kurikulum yang digunakan di SDLB adalah kurikulum yang digunakan di SLB untuk tingkat dasar yang disesuikan dengan kekhususannya. Kegiatan belajar dilakukan secara individual, kelompok, dan klasikal sesuai dengan ketunaan masingmasing. Pendekatan yang dipakai juga lebih ke pendekatan individualisasi.

3) Kelas Jauh

Kelas jauh adalah lembaga yang disediakan untuk memberi pelayanan pendidikan bagi anak berkebutuhan khusus dalam hal ini anak tunagrahita yang tinggal jauh dari SLB atau SDLB. Anak tunagrahita tersebar di seluruh pelosok tanah air, sedangkan sekolahsekolah yang khusus mendidik mereka masih sangat terbatas di kota/kabupaten. Pengelenggaraan kelas jauh merupakan kebijaksanaan pemerintah dalam rangka menuntaskan wajib belajar serta pemerataan kesempatan belajar.

Administrasi kelas jauh banyak dikerjakan di sekolah khusus (induknya), sedangkan administrasi kegiatan belajar mengajar dikerjakan oleh guru pada kelas jauh tersebut. Tenaga guru yang bertugas di kelas tersebut berasal dari guru SLBSLB di dekatnya. Mereka berfungsi sebagai guru kunjung.

4) Guru Kunjung

Berdasarkan kalsifikasinya terdapat anak anak tunagrahita yang mengalami kelainan berat sehingga tidak memungkinkan untuk berkunjung ke 
sekolah khusus. Oleh karena itu, guru berkunjung ke tempat anak tersebut dan memberi pelajaran sesuai dengan kebutuhan anak.

5) Lembaga Perawatan (Institusi Khusus)

Lembaga perawatan ini disediakan khusus untuk anak tunagrahita yang tergolong berat dan sangat berat. Di sana mereka mendapat layanan pendidikan dan perawatan sebab tidak jarang anak tunagrahita berat dan sangat berat menderita penyakit di samping ketunagrahitaan.

\section{b) Sekolah Umum dengan Sistem Integrasi (Terpadu)}

Sistem integrasi memberikan kesempatan kepada anak tunagrahita belajar, bermain atau bekerja bersama dengan anak normal. Pelaksanaan sistem terpadu bervariasi sesuai dengan taraf ketunagrahitaan. Berikut ini beberapa tempat pendidikan yang termasuk sistem integrasi, (adaptasi dari Moh, 1995).

1) Kelas Biasa Tanpa Kekhususan Baik Bahan Pelajaran Maupun Guru

Anak tunagrahita yang dimasukkan dalam kelas ini adalah yang paling ringan ketunagrahitaannya. Mereka tidak memerlukan bahan khusus ataupun guru khusus. Anak ini mungkin hanya memerlukan waktu belajar untuk bahan tertentu lebih lama dari rekan-rekannya yang normal. Mereka memerlukan perhatian khusus dari guru kelas (guru umum), misalnya penempatan tempat duduknya, pengelompokan dengan temantemannya, dan kebiasaan bertanggung jawab.

2) Kelas Biasa Dengan Guru Konsultan

Anak tunagrahita belajar bersamasama dengan anak normal di bawah pimpinan guru kelasnya. Sekali-sekali guru konsultan datang untuk membantu guru kelas dalam memahami masalah anak tunagrahita dan cara menanganinya, memberi petunjuk mengenai bahan pelajaran dan metode yang sesuai dengan keadaan anak tunagrahita.

3) Kelas Biasa Dengan Guru Kunjung

Anak tunagrahita belajar bersama-sama dengan anak normal di kelas biasa dan diajar oleh guru kelasnya. Guru kunjung mengajar anak tunagrahita apabila guru kelas mengalami kesulitan dan juga memberi petunjuk atau saran kepada guru kelas. Guru kunjung memiliki jadwal tertentu.

4) Kelas Biasa Dengan Ruang Sumber

Ruang sumber adalah ruangan khusus yang menyediakan berbagai fasilitas untuk mengatasi kesulitan belajar anak tunagrahita. Anak tunagrahita dididik di kelas biasa dengan bantuan guru pendidikan luar biasa di ruang sumber. Biasanya anak tunagrahita datang ke ruang sumber.

5) Kelas Khusus Sebagian Waktu

Kelas ini berada di sekolah biasa dan menampung anak tunagrahita ringan tingkat bawah atau tunagrahita sedang tingkat atas. Dalam beberapa hal, anak tunagrahita mengikuti pelajaran di kelas biasa bersama dengan anak normal. Apabila menyulitkan, mereka belajar di kelas khusus dengan bimbingan guru pendidikan luar biasa.

6) Kelas Khusus

Kelas ini juga berada di sekolah biasa yang berupa ruangan khusus untuk anak tunagrahita. Biasanya anak tunagrahita sedang lebih efektif ditempatkan di kelas ini. Mereka berintegrasi dengan anak yang normal pada waktu upacara, mengikuti pelajaran 
olahraga, perayaan, dan penggunaan kantin.

\section{c) Pendidikan Inklusif}

Sejalan dengan perkembangan layaan pendidikan untuk anak berkebutuhan khusus, terdapat kecenderungan baru yaitu model Pendidikan Inklusif. Model ini menekankan pada keterpaduan penuh, menghilangkan labelisasi anak dengan prinsip "Education for All”. Layanan pendidikan inklusif diselenggarakan pada sekolah reguler. Anak tunagrahita belajar bersama-sama dengan anak reguler, pada kelas dan guru/pembimbing yang sama. Pada kelas inklusi, siswa dibimbing oleh 2 (dua) orang guru, satu guru reguler dan satu lagu guru khusus. Guna guru khusus untuk memberikan bantuan kepada siswa tunagrahita jika anak tersenut mempunyai kesulitan di dalam kelas. Semua anak diberlakukan dan mempunyai hak serta kewajiban yang sama. Tapi saat ini pelayanan pendidikan inklusif masih dalam tahap rintisan

\section{Ciri Khusus dan Prinsip Khusus} Layanan yang Sesuai dengan Anak Tunagrahita

Ciri-ciri khusus dalam Layanan yang Sesuai dengan Anak Tunagrahita menurut Rochyadi (2005) antara lain :

1) Bahasa yang Digunakan

Bahasa yang digunakan dalam berinteraksi dengan anak tunagrahita adalah bahasa sederhana, tidak berbelit, jelas, dan gunakan kata-kata yang sering didengar oleh anak.

2) Penempatan Anak Tunagrahita di Kelas Anak tunagrahita ditempatkan di bagian depan kelas dan berdekatan dengan anak yang kira-kira hampir sama kemampuannya. Apabila mereka di kelas anak normal maka mereka ditempatkan dekat anak yang dapat menimbulkan sikap keakraban.

3) Ketersediaan Program Khusus Disamping ada program umum yang diperkirakan semua anak di kelas itu dapat memperlajarinya perlu disediakan program khusus untuk anak tunagrahita yang kemungkinan mengalami kesulitan. Sedangkan Prinsip khusus Layanan yang Sesuai dengan Anak Tunagrahita yaitu :

1) Prinsip Skala Perkembangan Mental

Prinsip ini menekankan pada pemahaman guru mengenai usia kecerdasan anak tunagrahita. Melalui prinsip ini dapat diketahui perbedaan antar dan intra individu.

2) Prinsip Kecekatan Motorik

Melalui prinsip ini anak tunagrahita dapat mempelajari sesuatu dengan melakukannya. Disamping itu, dapat melatih motorik anak terutama untuk gerakan yang kurang mereka kuasai.

3) Prinsip Keperagaaan

Prinsip ini digunakan dalam mengajar anak tunagrahita mengingat keterbatasan anak tunagrahita dalam berpikir abstrak. Oleh karena itu sangat penting, dalam mengajar anak tuangrahita dapt menggunakan alat peraga. Dengan alat peraga anak tunagrahita tidak verbalisme dan memiliki tanggapan mengenai apa yang dipelajarinya.

4) Prinsip Pengulangan

Berhubung anak tunagrahita cepat lupa mengenai apa yang dipelajarinya maka dalam mengajar mereka membutuhkan pengulanganpengulangan disertai contoh yang 
bervariasi. Oleh karena itu, dalam mengajar anak tunagrahita janglah cepat-cepat maju atau pindah ke bahan berikutnya sebelum guru yakin betul bahwa anak telah memahami betul bahan yang dipelajarinya.

5) Prinsip Korelasi

Maksud prinsip ini adalah bahan pelajaran dalam bidang tertentu hendaknya berhubungan dengan bidang lainnya atau berkaitan langsung dengan kegiatan kehidupan sehari-hari anak tunagrahita.

6) Prinsip Maju Berkelanjutan

Maksud prinsip ini adalah pelajaran diulangi dahulu dan apabila anak menunjukkan kemajuan, segera diberi bahan berikutnya.

7) Prinsip Individualisasi

Prinsip ini menekankan perhatian pada perbedaan individual anak tunagrahita. Anak tunagrahita belajar sesuai dengan iramanya sendiri. Namun, mereka harus berinteraksi dengan teman atau dengan lingkungannya. Jadi, mereka tetap belajar bersama dalam satu ruangan dengan kedalaman dan keluasan materi yang berbeda.

\section{Strategi dan Media Pembelajaran dalam Pendidikan Anak Tunagrahita}

Strategi yang dapat digunakan dalam mengajar anak tunagrahita menurut Rochyadi (2005) meliputi:

\section{1) Strategi Pengajaran yang Diindividualisasikan}

Pengajaranyang

diindividualisasikan merupakan pengajaran diberikan kepada tiap murid meskipun mereka belajar bersama dengan bidang studi yang sama, tetapi kedalaman dan keluasan materi pelajaran disesuaikan dengan kemampuan dan kebutuhan tiap anak. Dalam pelaksanaannya guru perlu melakukan hal-hal berikut ini.

$\begin{array}{lll}\text { a) Pengelompokan murid yang } \\ \text { memungkinkan } & \text { murid dapat }\end{array}$ berinteraksi, bekerja sama, dan bekerja selaku anggota kelompok dan tidak menjadi anggota tetap dalam kelompok tertentu. Kedudukan murid dalam kelompok sesuai dengan minat, dan kemampuan belajar yang hampir sama.

b) Pengaturan lingkungan belajar yang memungkinkan murid melakukan kegiatan yang beraneka ragam, dapat berpindah tempat sesuai dengan kebutuhan murid tersebut, serta adanya keseimbangan antara bagian yang sunyi dan gaduh dalam pekerjaan di kelas. Adanya petunjuk tentang penggunaan tiap bagian, adanya pengaturan agar memudahkan bantuan dari orang yang dibutuhkan. Posisi tempat duduk (kursi \& meja) dapat berubah-ubah, ukuran barang dan tata letaknya hendaknya dapat dijangkau oleh murid sehingga memungkinkan murid dapat mengatur sendiri kebutuhan belajarnya.

c) Mengadakan Pusat Belajar (Learning Centre)

Pusat belajar ini dibentuk pada sudutsudut ruangan kelas, misalnya sudut bahasa, sudut IPA, berhitung. Pembagian seperti ini, memungkinkan anak belajar sesuai dengan pilihannya sendiri. Di pusat belajar itu tersedia pelajaran yang akan dilakukan, tersedianya tujuan Pembelajaran Khusus sehingga mengarahkan kegiatan belajar yang lebih banyak bernuansa aplikasi, seperti mengisi, mengatur, menyusun, mengumpulkan, memisahkan, mengklasifikasi, menggunting, membuat bagan, menyetel, mendengarkan, 
mengobservasi. Selain itu, pada tiap pusat belajar tersedia bahan yang dapat dipilih dan digunakan oleh anak itu sendiri. Melalui strategi ini anak akan maju sesuai dengan irama belajarnya sendiri dengan tidak terlepas dari interaksi sosial.

\section{2) Strategi Kooperatif}

Strategi ini merupakan strategi yang paling efektif diterapkan pada kelompok murid yang memiliki kemampuan heterogen, misalnya dalam pendidikan yang mengintegrasikan anak tunagrahita belajar bersama dengan anak normal. Strategi kooperatif memiliki keunggulan, seperti meningkatkan sosialisasi antara anak tunagrahita dengan anak normal, menumbuhkan penghargaan dan sikap positif anak normal terhadap prestasi belajar anak tunagrahita sehingga memungkinkan harga diri anak tunagrahita meningkat, dan memberi kesempatan pada anak tunagrahita untuk mengembangkan potensinya seoptimal mungkin.

Dalam pelaksanaannya guru harus memiliki kemampuan merumuskan tujuan pembelajaran, guru dituntut mempunyai keterampilan untuk mengatur tempat duduk, pengelompokan anak dan besarnya anggota kelompok. Jonshon (1984) mengemukakan bahwa guru harus mampu merancang bahan pelajaran dan peran tiap anak yang dapat menunjang terciptanya ketergantungan positif antara anak tunagrahita ringan dengan anak normal.

\section{3) Strategi Modifikasi Tingkah Laku}

Strategi ini digunakan apabila menghadapi anak tunagrahita sedang ke bawah atau anak tunagrahita dengan gangguan lain. Tujuan strategi ini adalah mengubah, menghilangkan atau mengurangi tingkah laku yang tidak baik ke tingkah laku yang baik.

Dalam pelaksanaannya guru harus terampil memilih tingkah laku yang harus dihilangkan. Sementara itu perlu pula teknik khusus dalam melaksanakan modifikasi tingkah laku tersebut, seperti reinforcement dapat berupa pujian, hadiah atau elusan. Pujian diberikan apabila siswa menunjukkan perilaku yang dikehendaki oleh guru. Dan pemberian reinforcement itu makin hari makin dikurangi agar tidak terjadi ketergantungan.

\section{Media Pembelajaran dalam Pendidikan Anak Tunagrahita}

Media pembelajaran penting diperhatikan dalam mengajar anak tunagrahita (Rochyadi, 2005). Hal ini disebabkan anak tunagrahita kurang mampu berfikir abstrak, mereka membtutuhkan hal-hal kongkrit. Agar terjadinya tanggapan tentang obyek yang dipelajari, maka dibutuhkan media pembelajaran yang memadai.

Selanjutnya diterangkan tentang karakteristik media pembelajaran pelajaran untuk anak tunagrahita antara lain : (1) Bahan tidak berbahaya bagi anak, mudah diperoleh, dapat digunakan oleh anak, (2) Warna tidak mencolok dan tidak abstrak, dan (3) Ukurannya harus dapat digunakan atau diatur penggunaannya oleh anak itu sendiri (ukuran meja dan kursi).

Adapun media pembelajaran untuk anak tunagrahita yaitu alat latihan kematangan motorik berupa form board, puzzle; latihan kematangan indra, seperti latihan perabaan, penciuman; alat latihan untuk mengurus diri sendiri, seperti latihan memasang kancing, memasang retsluiting; alat latihan konsentrasi, seperti papan 
keseimbangan, alat latihan membaca, berhitung, dan lain-lain.

\section{Ketentuan Khusus dalam \\ Melaksanakan Evaluasi Belajar Anak Tunagrahita}

Berikut ini akan dikemukakan ketentuan-ketentuan khusus dalam melaksanakan evaluasi belajar anak tunagrahita (Rochyadi, 2005).

\section{a. Waktu Mengadakan Evaluasi}

Evaluasi belajar anak tunagrahita tidak saja dilakukan pada saat kegiatan belajar mengajar berakhir, namun juga dilaksnakaan selama proses belajar mengajar berlangsung. Pada saat itu dapat dilihat bagaimana reaksi anak, sikap anak, kecepatan atau kelambatan setiap anak. Apabila ditemukan anak yang lebih cepat dari temannya maka ia segera diberi bahan pelajaran berikutnya tanpa harus menunggu teman-temanya, sedangkan anak yang lebih lambat, mendapatkan pengulangan atau penyederhanaan materi pelajaran.

\section{b. Alat Evaluasi}

Alat evaluasi yang digunakan untuk menilai hasil belajar anak tunagrahita sama dengan anak normal, kecuali dalam bentuk dan urutan penggunaannya. Penggunaan alat evaluasi, seperti tulisan, lisan dan perbuatan bagi anak tunagrahita harus ditinjau lebih dahulu bagaimana keadaan anak tunagrahita yang akan dievaluasi. Misalnya, anak tunagrahita sedang tidak mungkin diberikan alat evaluasi tulisan. Mereka diberikan alat evaluasi perbuatan dan bagi anak tunagrahita ringan dapat diberikan alat evaluasi tulisan maupun lisan karena anak tunagrahita ringan masih memiliki kemampuan untuk menulis dan membaca serta berhitung walaupun tidak seperti anak normal pada umumnya.

Kemudian, kata tanya yang digunakan adalah kata yang tidak menuntut uraian (bagaimana, mengapa), tetapi kata apa, siapa atau di mana.

\section{c. Kriteria Keberhasilan}

Keberhasilan belajar anak tunagrahita dibandingkan dengan kemajuan yang dicapai oleh anak itu sendiri dari waktu ke waktu. Oleh karena itu, penilaian pada anak tunagrahita adalah longitudinal maksudnya penilaian yang mengacu pada perbandingan prestasi individu atas dirinya sendiri yang dicapainya kemarin dan hari ini.

\section{d. Pencatatan Hasil Evaluasi}

Pencatatan evaluasi untuk anak tunagrahita menggunakan bentuk kuantitatif ditambah dengan kualitatif. Misalnya, dalam pelajaran Berhitung, murid mendapat nilai angka 7. Sebaiknya diikuti dengan penjelasan, seperti nilai 7 berarti dapat mempelajari penjumlahan 1 sampai 4, pengurangan 1 sampai 3 .

\section{SIMPULAN}

Berdasarkan pada hasil pembahasan di atas, maka dapat ditarik suatu simpulan sebagai berikut:

1) Seseorang dikatakan tunagrahita apabila anak tersebut memiliki tingkat kecerdasan dibawah rata-rata sehingga mereka sulit menyusuaikan diri dengan lingkungannya. Mereka juga tidak mampu memikirkan hal yang bersifat abstrak dan pelajaran yang bersifak akademik.

2) Anak tunagrahita dapat dikelompokkan menjadi tunagrahita ringan, tunagrahita 
sedang, tunagrahita berat dan tunagrahita sangat berat.

3) Tempat dan sistem pendidikan pendidikan anak tunagrahita meliputi tempat khusus atau sistem segregasi, sekolah umum dengan sistem integrasi (terpadu), dan pendidikan inklusif

4) Strategi pembelajaran yang sesuai dengan kebutuhan anak tunagrahita akan meliputi strategi pengajaran yang diindividualisasikan, kooperatif dan modifikasi tingkah laku.

5) Media pelajaran anak tunagrahita selain media yang biasa digunakan pada proses belajar secara umum diperlukan media khusus, seperti media untuk latihan motorik, latihan keseimbangan, dan latihan konsentrasi.

6) Evaluasi belajar anak tunagrahita mengacu pada evaluasi belajar anak biasa. Hanya saja perlu dimodifikasi dalam waktu pelaksanaan evaluasi, alat evaluasi, kriteria keberhasilan dan pencatatan hasil evaluasi.

\section{Saran}

Berdasarkan dari hasil penulisan artikel ini dapat disarankan kepada guruguru khususnya guru yang memiliki anak didik tunagrahita hendaknya dapat mengenali ciri-ciri mereka sehingga mampu menfkasifikasikan termasuk dalam kategori tunagrahita yang mana dan mampu memeberikan layana pendidikan yang sesuai, serta mampu merancang strategi, media, evaluasi yang sesuai dengan ketunagrahittaan yang mereka alami.

\section{DAFTAR PUSTAKA}

Efendi, M. (2006). Pengantar psikologi anak berkelainan. Jakarta: Bumi Aksara.

Endang, R. dan Alimin, Z. (2005). Pengembangan program pembelajaran individual bagi anak tuna grahita. Jakarta: Depdiknas

Moh. A. (1995). Ortopedagogik anak tunagrahita. Jakarta: Direktorat Jenderal Pendidikan Tinggi Departemen Pendidikan dan Kebudayaan.

Mumpuniarti.(2007). Pembelajaran akademik bagi tunagrahita. Yogyakarta: FIP UNY.

Suhaeri H.N. (1979). Penyelidikan tentang persepsi visual anak terbelakang. Bandung: PLB FIP IKIP. 